Article

\title{
Synergistic Effect of Photocatalytic Degradation of Hexabromocyclododecane in Water by $\mathrm{UV} / \mathrm{TiO}_{2} /$ persulfate
}

\author{
Qiang $\mathrm{Li}^{1,2}$, Lifang Wang ${ }^{1}$, Xuhui Fang ${ }^{3}$, Li Zhang ${ }^{2, *}$, Jingjiu $\mathrm{Li}^{2}$ and Hongyong $\mathrm{Xie}^{2, *}$ \\ 1 School of Management, Northwestern Polytechnical University, 127 West Youxi Road, Xian 710072, China; \\ failureend@163.com (Q.L.); lifang@nwpu.edu.cn (L.W.) \\ 2 Research Center of Resource Recycling Science and Engineering, School of Environmental and Materials \\ Engineering, Shanghai Polytechnic University, Shanghai 201209, China; lijingjiu123@163.com \\ 3 Centre Testing International Pinbiao (Shanghai) Co., Ltd., 1996 New Jinqiao Road, Shanghai 201206, China; \\ fangxuwh@126.com \\ * Correspondence: zhangli@sspu.edu.cn (L.Z.); hyxie@sspu.edu.cn (H.X.); \\ Tel.: +86-021-5021-1210 (L.Z.); +86-021-5021-1231 (H.X.)
}

Received: 4 January 2019; Accepted: 31 January 2019; Published: 18 February 2019

\begin{abstract}
In this work, the elimination of hexabromocyclododecane (HBCD) is explored by using photodegradation of the $\mathrm{UV} / \mathrm{TiO}_{2}$ system, the $\mathrm{UV} /$ potassium persulfate (KPS) system, and the homo/heterogeneous $\mathrm{UV} / \mathrm{TiO}_{2} / \mathrm{KPS}$ system. The experimental results show that the dosages of $\mathrm{TiO}_{2}$ and potassium persulfate have optimum values to increase the degradation degree. $\mathrm{HBCD}$ can be almost completely degraded and $74.3 \%$ of the total bromine content is achieved in the UV/ $/ \mathrm{TiO}_{2} / \mathrm{KPS}$ homo/heterogeneous photocatalysis, much more than in the UV/persulfate system and the $\mathrm{UV} / \mathrm{TiO}_{2}$ system. Roles of radicals $\mathrm{SO}_{4}{ }^{-}$and $\mathrm{OH}^{\bullet}$ in the photocatalysis systems are discussed based on experimental measurements. The high yield of the concentration of bromide ions and decreased $\mathrm{pH}$ value indicates that synergistic effects exist in the $\mathrm{UV} / \mathrm{TiO}_{2} / \mathrm{KPS}$ homo/heterogeneous photocatalysis, which can mineralize $\mathrm{HBCD}$ into inorganic small molecules like carboxylic acids, $\mathrm{CO}_{2}$ and $\mathrm{H}_{2} \mathrm{O}$, thus much less intermediates are formed. The possible pathways of degradation of HBCD in the $\mathrm{UV} / \mathrm{TiO}_{2} / \mathrm{KPS}$ system were also analyzed by GC/MS. This work will have practical application potential in the fields of pollution control and environmental management.
\end{abstract}

Keywords: hexabromocyclododecane; environmental management; photocatalysis; advanced oxidation processes

\section{Introduction}

Hexabromocyclododecane (HBCD) is a high bromine content additive flame retardant that is mainly used in polystyrene electrical equipment, insulation boards, resin, polyester fabric, synthetic rubber coating, and so on [1]. Studies have shown that HBCD is a potential endocrine disruptor, and it has immunotoxicity, neurotoxicity, and cytotoxicity [2]. The presence of HBCD was detected in environmental samples such as water, atmosphere, sediment, soil, food, and even in the human body in breast milk and plasma, as it can be enriched through the food chain, causing persistent pollution [3]. The hazard of HBCD and its pollution in the environment have caused widespread concern, and it is of great significance to develop a strategy for the elimination of HBCD pollution [4]. However, the molecular structure of $\mathrm{HBCD}$ with a ring structure is relatively stable, making it heat-resistant, UV-resistant, and difficult to be decomposed in the natural environment [5]. Methods for eliminating HBCD in the environment include microbial degradation, ultrasonic degradation, chemical reduction, phytoremediation, and mechanical ball milling [6-8]. However, these methods 
have not been practically used because of the harsh reaction conditions, high energy consumption, low efficiency, and secondary pollution $[9,10]$. Nowadays, advanced oxidation processes (AOPs) have been widely used for the elimination of organic pollutants of water or gas, using the highly reactive chemical species like hydroxyl radicals $\left(\mathrm{OH}^{\bullet}\right)$ to oxidize most of pollutants into small molecular substances that are harmless to the environment, such as $\mathrm{CO}_{2}, \mathrm{H}_{2} \mathrm{O}$ and so on [11]. Increasing the number of hydroxyl radicals could increase the efficiency of the AOPs reactions. Some types of AOPs based on UV, $\mathrm{H}_{2} \mathrm{O}_{2} / \mathrm{UV}, \mathrm{O}_{3} / \mathrm{UV}$ and $\mathrm{H}_{2} \mathrm{O}_{2} / \mathrm{O}_{3} / \mathrm{UV}$ combinations use photolysis of $\mathrm{H}_{2} \mathrm{O}_{2}$ and ozone to produce $\mathrm{OH}^{\bullet}$, while the heterogeneous $\mathrm{UV} / \mathrm{TiO}_{2}$ photocatalysis and homogeneous photo-Fenton are based on the use of a wide-band gap semiconductor and addition of $\mathrm{H}_{2} \mathrm{O}_{2}$ to dissolved iron salts that produce $\mathrm{OH}^{\bullet}$ under UV irradiation, respectively [12]. Among AOPs, the $\mathrm{UV} / \mathrm{TiO}_{2}$ heterogeneous photocatalysis has gradually attracted the interest of scientists in elimination of toxic pollutions due to its efficiency, low-cost and broad applicability [13]. The photocatalytic technology can be briefly described as follows: under UV irradiation, the electron in $\mathrm{TiO}_{2}$ was excited and transferred from the valence band (VB) to the conduction band (CB), resulting in the formation of high energy electron-hole pairs; the electrons may also react with $\mathrm{O}_{2}$ and generate a superoxide ion $\left(\mathrm{O}_{2}{ }^{\bullet-}\right)$, while holes were captured by surface hydroxyl groups $\left(\mathrm{OH}^{-}\right)$on the photocatalyst surface to yield $\mathrm{OH}^{\bullet}[14,15]$. However, the photogenerated electron-hole pairs are easy to combine within a very short time of $10^{-9} \sim 10^{-12} \mathrm{~s}$, which results in a lower photocatalytic degradation efficiency [16]. In order to solve this problem, scientists have conducted lots of meaningful and in-depth research. For instance, Aronne et al. found that high $\mathrm{Ti}^{3+}$ self-doping $\mathrm{TiO}_{2-x}$ not only has a wide range of visible light responses, but also has a low recombination rate of electron-hole pairs [17]; Sannino et al. fabricated hybrid $\mathrm{TiO}_{2}$-acetylacetonate amorphous gel-derived material with stably adsorbed superoxide radical $\left(\mathrm{O}_{2}{ }^{\bullet-}\right)$ active in oxidative degradation of organic pollutants in the absence of any light irradiation $[18,19]$.

It has been reported that using the strong oxidant of persulfate ion $\left(\mathrm{S}_{2} \mathrm{O}_{8}{ }^{2-}\right.$ ) (with redox potential of $2.05 \mathrm{~V}$ ) is effective for degrading organic pollutions in water solution through direct chemical oxidation [20]. The $\mathrm{S}_{2} \mathrm{O}_{2}{ }^{-}$can be activated via thermal, UV light, or redox decomposition to generate the stronger oxidant of sulfate radicals $\left(E_{0}=(2.5-3.1) \mathrm{V}\right.$ vs. NHE) [21-23]. It's worthwhile to note that both the persulfate ion and sulfate radicals $\left(\mathrm{SO}_{4}{ }^{--}\right)$can be dissolved in water, so the free radicals and contaminants in water can be contracted at the molecular level, leading to a higher reaction rate. For instance, $\mathrm{Li}$ et al. have found that addition of persulphate to $\mathrm{UV} / \mathrm{TiO}_{2}$ could improve the photocatalytic degradation of tetrabromobisphenol A and other pollutants [24-26]. Therefore, it is necessary to combine persulfate and $\mathrm{UV} / \mathrm{TiO}_{2}$ photocatalytic techniques to increase the mineralization of HBCD.

In this work, degradation of $\mathrm{HBCD}$ under $\mathrm{UV} / \mathrm{TiO}_{2}, \mathrm{UV} /$ potassium persulfate (KPS), and $\mathrm{UV} / \mathrm{TiO}_{2} / \mathrm{KPS}$ systems were investigated. Effects of $\mathrm{TiO}_{2}$ and $\mathrm{KPS}$ dosage have been examined on degradation degree of HBCD. The photodegradation efficiency and the yield of bromide ion were tested to evaluate the mineralization of $\mathrm{HBCD}$. The intermediates were analyzed by GC/MS to study the degradation mechanism. Based on experimental measurements, roles of radicals $\mathrm{SO}_{4}{ }^{\bullet-}$ and $\mathrm{OH}^{\bullet}$ in the photocatalysis systems were also discussed.

\section{Results and Discussions}

\subsection{Determination of $\mathrm{TiO}_{2}$ Dosages}

The amount of catalysts added in the solution needs to be matched to the number of contaminants in the photocatalytic process, so the dosing weight range of the catalyst were determined. Figure 1 shows the effects of different $\mathrm{TiO}_{2}$ dosages on the photodegradation rate of HBCD. Under the condition of no addition of $\mathrm{TiO}_{2}$, the degradation rate was only $21.5 \%$ at $180 \mathrm{~min}$. Having increased the catalyst dosage of $\mathrm{TiO}_{2}$ to $100 \mathrm{mg} / \mathrm{L}$, the photocatalytic efficiency also increased to $82.93 \%$. Further increasing the dosage of $\mathrm{TiO}_{2}$ more than $100 \mathrm{mg} / \mathrm{L}$, the photocatalytic efficiency decreased. The dosage of the 
addition increased the suspended particles in the solution, and greatly reduced the utilization of light, resulting in the partial catalyst not being fully activated during the photocatalysis, so the photocatalytic efficiency decreased [24,27]. In addition, the HBCD adsorbed on the catalysts in dark is less than $10 \%$, so the free radical $\left(\mathrm{OH}^{\bullet}\right)$ reaction dominates the rate of degradation reaction in the $\mathrm{UV} / \mathrm{TiO}_{2}$ system.

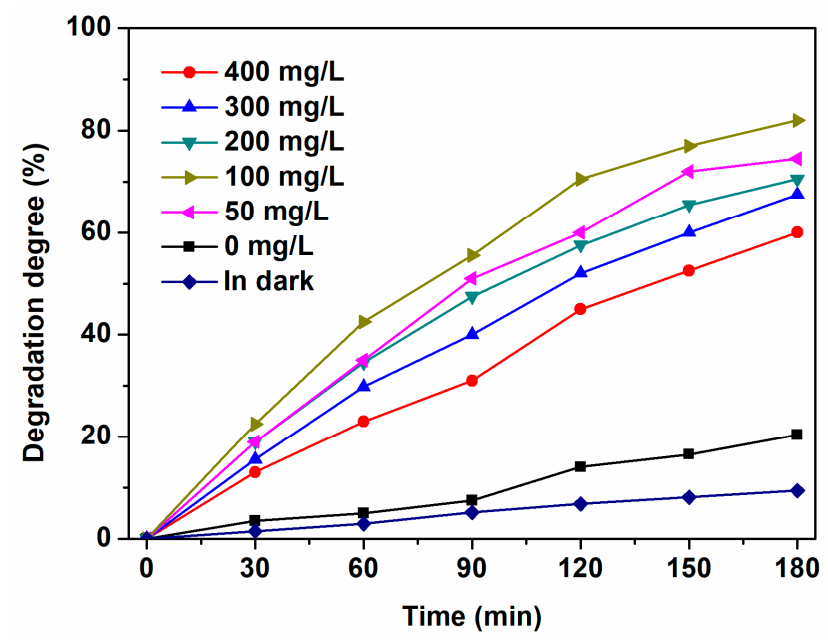

Figure 1. Effects of different $\mathrm{TiO}_{2}$ dosages on the photodegradation rate of $\mathrm{HBCD}$ (the initial concentration of $\mathrm{HBCD}$ is $25 \mathrm{mg} / \mathrm{L}$, and KPS dosage is $0 \mathrm{mg} / \mathrm{L}$ ).

\subsection{Effect of KPS Dosage}

Figure 2 shows the effect of different $\mathrm{K}_{2} \mathrm{~S}_{2} \mathrm{O}_{8}$ dosages on the photodegradation rate of HBCD. The addition of $\mathrm{K}_{2} \mathrm{~S}_{2} \mathrm{O}_{8}$ can effectively improve the degradation efficiency of $\mathrm{HBCD}$, but its degradation efficiency increases first and then decreases with further increasing $\mathrm{K}_{2} \mathrm{~S}_{2} \mathrm{O}_{8}$ concentration, and the highest degradation efficiency occurs at $4 \mathrm{mM}$. When the $\mathrm{K}_{2} \mathrm{~S}_{2} \mathrm{O}_{8}$ dosage was more than $4 \mathrm{mM}$, the degradation efficiency of $\mathrm{HBCD}$ decreased with the increase of persulfate dosage. When the $\mathrm{K}_{2} \mathrm{~S}_{2} \mathrm{O}_{8}$ concentrations in the solution are between 0 and $4 \mathrm{mM}$, the main reactions in the UV/ $\mathrm{TiO}_{2} / \mathrm{KPS}$ system are as follows [28]:

$$
\begin{aligned}
& \mathrm{S}_{2} \mathrm{O}_{8}{ }^{2-}+\mathrm{UV} \rightarrow 2 \mathrm{SO}_{4}{ }^{--} \\
& \mathrm{TiO}_{2}+\mathrm{UV} \rightarrow \mathrm{e}_{\mathrm{CB}}^{-}+\mathrm{h}_{\mathrm{VB}}^{+} \\
& \mathrm{S}_{2} \mathrm{O}_{8}{ }^{2-}+\mathrm{e}_{\mathrm{CB}}^{-} \rightarrow 2 \mathrm{SO}_{4}{ }^{\bullet-} \\
& \mathrm{H}_{2} \mathrm{O}+\mathrm{h}_{\mathrm{VB}}^{+} \rightarrow \mathrm{OH}^{\bullet}+\mathrm{H}^{+}
\end{aligned}
$$

The advanced oxidation process relies on the amount of free radicals and is reflected in the degradation rate of the contaminants. The strong oxidizing agents of sulfate radicals $\left(\mathrm{SO}_{4}{ }^{\bullet-}\right)$ and hydroxyl radicals $\left(\mathrm{OH}^{\bullet}\right)$ generated by the above reactions increase with increasing KPS concentration in the solution. But increasing the KPS dosage further to $8 \mathrm{mM}$ will lead to a surplus of reactants $\left(\mathrm{S}_{2} \mathrm{O}_{8}{ }^{2-}\right)$, which may deplete lots of $\mathrm{OH}^{\bullet}$ and $\mathrm{SO}_{4}{ }^{\bullet-}$, and lead to the decrease of the degradation degree by the following two reactions [29]:

$$
\begin{gathered}
\mathrm{S}_{2} \mathrm{O}_{8}{ }^{2-}+\mathrm{OH}^{\bullet} \rightarrow \mathrm{S}_{2} \mathrm{O}_{8}{ }^{\bullet-}+\mathrm{OH}^{-} \\
\mathrm{S}_{2} \mathrm{O}_{8}{ }^{2-}+\mathrm{SO}_{4}{ }^{\bullet-} \rightarrow \mathrm{SO}_{4}{ }^{2-}+\mathrm{S}_{2} \mathrm{O}_{8}{ }^{\bullet-}
\end{gathered}
$$




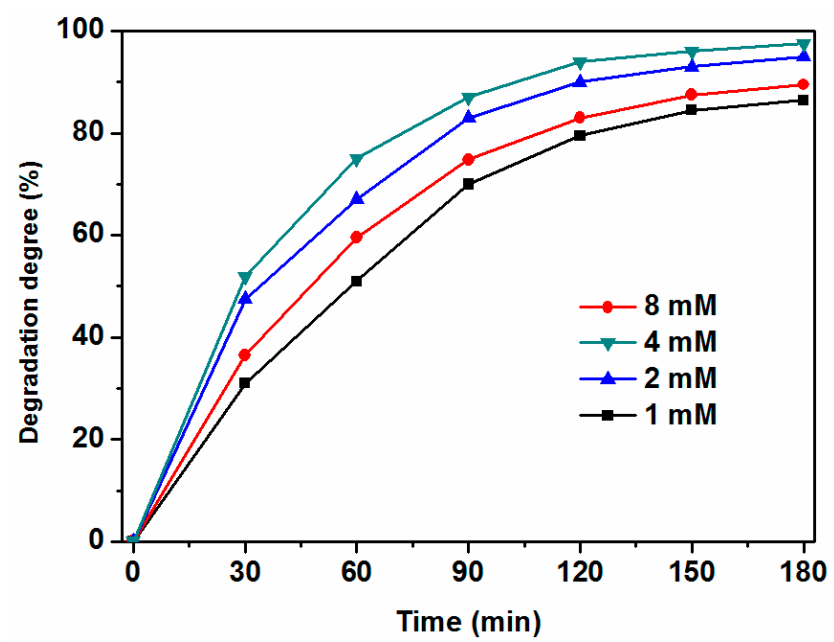

Figure 2. Effects of different KPS dosages on the photodegradation rate of HBCD (the initial concentration of $\mathrm{HBCD}$ is $25 \mathrm{mg} / \mathrm{L}$, and $\mathrm{TiO}_{2}$ dosage is $100 \mathrm{mg} / \mathrm{L}$ ).

\subsection{Kinetic Analysis of Different Reaction Systems}

Figure 3 shows the degradation effect of $\mathrm{HBCD}$ in the three systems of "UV/ $\mathrm{TiO}_{2}\left(\mathrm{TiO}_{2}\right.$ : $100 \mathrm{mg} / \mathrm{L}$ )", "UV/ $\mathrm{K}_{2} \mathrm{~S}_{2} \mathrm{O}_{8}$ (KPS: $\left.4 \mathrm{mM}\right)$ ", and " $\mathrm{TiO}_{2}\left(\mathrm{TiO}_{2}: 100 \mathrm{mg} / \mathrm{L}\right)+\mathrm{K}_{2} \mathrm{~S}_{2} \mathrm{O}_{8}(\mathrm{KPS}: 4 \mathrm{mM})$ ", respectively. The initial $\mathrm{HBCD}$ concentration and light source in the three systems were all the same ( $25 \mathrm{mg} / \mathrm{L}, 100 \mathrm{~W}$ mercury lamp). The degradation degree of HBCD over time in $180 \mathrm{~min}$ is shown in Figure 3a. The degradation degree for the UV $/ \mathrm{TiO}_{2} / \mathrm{KPS}$ photocatalytic system was $87.6 \%$ at $90 \mathrm{~min}$, but the degradation rates for the $\mathrm{UV} / \mathrm{TiO}_{2}$ photocatalytic system and UV/KPS system were only $56.8 \%$ and $52.5 \%$ at the same time. The above experimental results show that the degradation effect of $\mathrm{UV} / \mathrm{TiO}_{2} / \mathrm{KPS}$ photocatalytic system on $\mathrm{HBCD}$ is far superior to that of the $\mathrm{UV} / \mathrm{TiO}_{2}$ system and the $\mathrm{UV} / \mathrm{KPS}$ system.

The kinetic model was used to study the degradation dynamic behavior of the three different systems [30], $-\ln \left(C_{0} / C\right)=k t$, where $k$ is the reaction apparent rate constant and $t$ is the light irradiation time. Figure $3 b$ shows the effect of different systems on the kinetics of HBCD under irradiation for $180 \mathrm{~min}$. The three reaction systems are all fit to pseudo-first-order kinetics, and the $k$ values for the UV/KPS system, the UV/ $\mathrm{TiO}_{2}$ system, and the $\mathrm{UV} / \mathrm{TiO}_{2} / \mathrm{KPS}$ system are $0.0065,0.0080$, and $0.0174 \mathrm{~min}^{-1}$, respectively (Figure 3b). Obviously, the $k$ value of the $\mathrm{UV} / \mathrm{TiO}_{2} / \mathrm{KPS}$ system is far higher than those of the UV/KPS system and the $\mathrm{UV} / \mathrm{TiO}_{2}$ system, indicating that the degradation efficiency of the $\mathrm{UV} / \mathrm{TiO}_{2} / \mathrm{KPS}$ photocatalytic system is much higher than that of the UV/KPS photocatalytic system and the $\mathrm{UV} / \mathrm{TiO}_{2}$ photocatalytic system. The photocatalytic process of the $\mathrm{UV} / \mathrm{TiO}_{2}$ system contains an adsorption and free radical $\left(\mathrm{O}_{2}{ }^{\bullet-}, \mathrm{OH}^{\bullet}\right.$, etc.) reaction [21]. The HBCD adsorbed on the catalysts in dark is less than $10 \%$, so the free radical reaction dominates the rate of degradation reaction in the $\mathrm{UV} / \mathrm{TiO}_{2}$ system. The $\mathrm{UV} / \mathrm{KPS}$ system also relies on sulfate radicals $\left(\mathrm{SO}_{4}{ }^{\bullet-}, \mathrm{S}_{2} \mathrm{O}_{8}{ }^{\bullet-}\right.$, etc.) excited by UV light to degrade pollutants [22,24]. In the $\mathrm{UV} / \mathrm{TiO}_{2} / \mathrm{KPS}$ system, more free radicals were present and the free radical reaction is more complicated. $\mathrm{S}_{2} \mathrm{O}_{8}{ }^{2-}$ can be excited by photogenerated electrons on the surface of the catalyst to generate sulfate radicals $\left(\mathrm{SO}_{4}{ }^{--}\right)$, while $\mathrm{SO}_{4}{ }^{\bullet-}$ can react with $\mathrm{OH}^{-}$to produce $\mathrm{OH}^{\bullet}$ [21-24]. In the three systems, the degradation rates are all determined by the reactions between free radicals and contaminant molecules, while the intensity of the UV light $(100 \mathrm{~W})$ and the initial concentration $(25.00 \mathrm{mg} / \mathrm{L})$ of the contaminants in the three systems are all the same, so all reaction systems could be in line with pseudo-first-order kinetics. Figure S1 (Supporting Information) shows the degradation of $\mathrm{HBCD}$ over the UV/ $\mathrm{TiO}_{2} / \mathrm{KPS}$ system with three time cycling uses. The $\mathrm{TiO}_{2}$ photocatalysts could be easily recovered by sedimentation and reused, which would greatly promote their industrial application in eliminating organic pollutants from wastewater. 

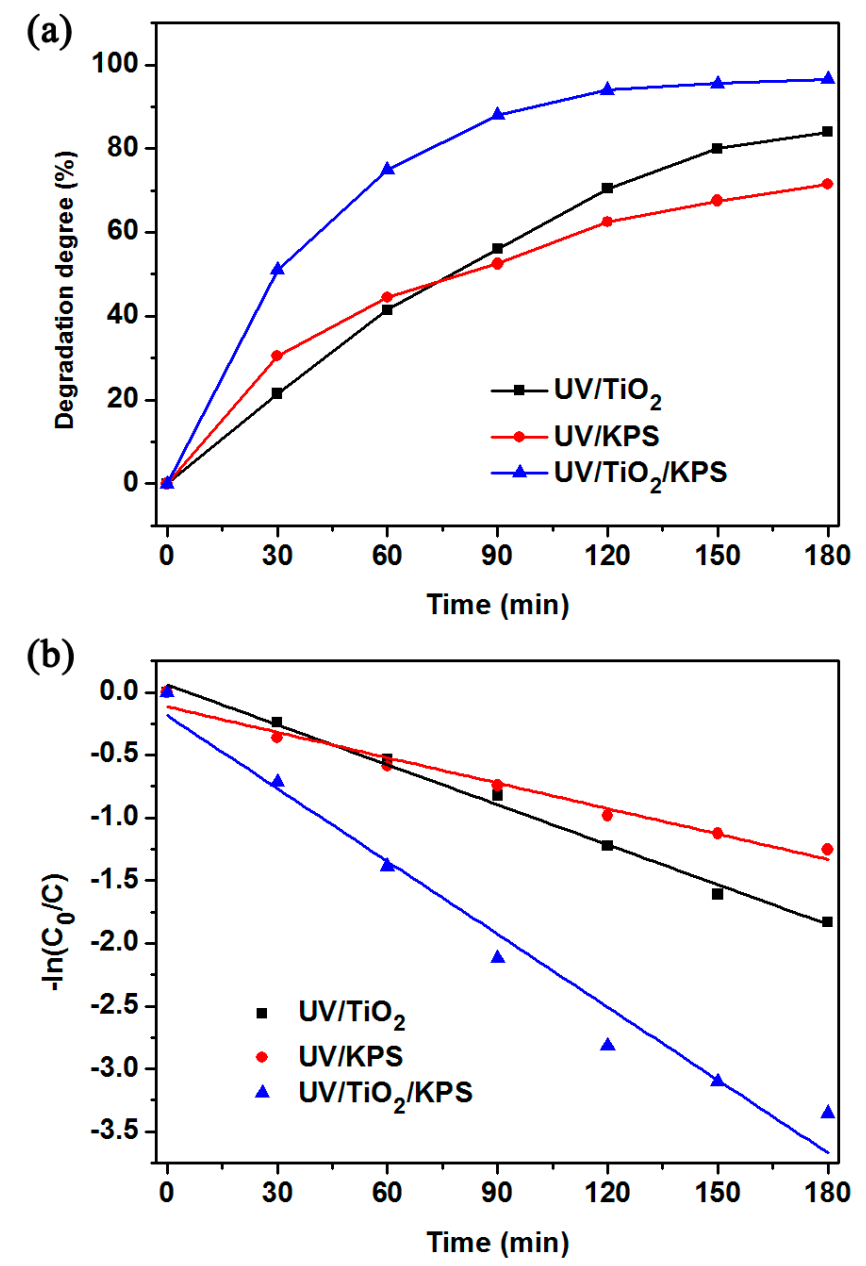

Figure 3. The degradation degree (a) and kinetic linear simulation curves of the removal of HBCD (b) in $\mathrm{UV} / \mathrm{TiO}_{2}, \mathrm{UV} / \mathrm{KPS}$, and $\mathrm{UV} / \mathrm{TiO}_{2} / \mathrm{KPS}$ systems. (The initial concentration of $\mathrm{HBCD}$ is $25.0 \mathrm{mg} / \mathrm{L}$, KPS dosage is $4 \mathrm{mg} / \mathrm{L}$, and $\mathrm{TiO}_{2}$ dosage is $100 \mathrm{mg} / \mathrm{L}$ ).

\subsection{The Mineralization Degree of $H B C D$}

Measuring the concentration of bromide ion is a practical strategy to evaluate the amount of intermediates and the mineralization degree of HBCD [24]. Figure 4 shows the change of bromide ion concentration during the degradation of $\mathrm{HBCD}$ in the $\mathrm{UV} / \mathrm{TiO}_{2} / \mathrm{KPS}$ system. The initial HBCD concentration, $\mathrm{TiO}_{2}$ dosage, and $\mathrm{K}_{2} \mathrm{~S}_{2} \mathrm{O}_{8}$ dosage were $25.0 \mathrm{mg} / \mathrm{L}, 100 \mathrm{mg} / \mathrm{L}$, and $4 \mathrm{mM}$, respectively.

As can be seen from Figure 4, with the prolongation of degradation time, the concentration of bromide ion in the solution increased continuously. When the reaction was carried out for $3.0 \mathrm{~h}$, the concentration of bromide ions in the solution was $13.8 \mathrm{mg} / \mathrm{L}$, which accounted for $74.3 \%$ of the total bromine content of $\mathrm{HBCD}$ in the solution. It can be seen that the yield of bromine ion by UV $/ \mathrm{TiO}_{2} / \mathrm{KPS}$ system is much better than that of $\mathrm{UV} / \mathrm{TiO}_{2}$ system $(12.3 \mathrm{mg} / \mathrm{L})$ and $\mathrm{UV} / \mathrm{KPS}$ system $(11.9 \mathrm{mg} / \mathrm{L})$. The significantly increased bromide ion concentration yield indicates that there exist synergistic effects in the UV/ $/ \mathrm{TiO}_{2} / \mathrm{KPS}$ photocatalysis as described in the previous Formulas (1)-(4), which can mineralize HBCD into inorganic small molecules relatively thorough, thus much fewer intermediates are formed in $\mathrm{UV} / \mathrm{TiO}_{2} / \mathrm{KPS}$ homo/heterogeneous photocatalysis.

Figure 5 shows the change of $\mathrm{pH}$ in solution over time during HBCD degradation. It can be seen that the $\mathrm{pH}$ value of the solution gradually decreases from 6.53 to 3.72 with the increasing of the degradation time within $180 \mathrm{~min}$. It may be due to the partial consumption of $\mathrm{OH}^{-}$in the solution, since $\mathrm{OH}^{-}$can easily react with $\mathrm{SO}_{4}{ }^{--}$to produce $\mathrm{OH}^{\bullet}$. The $\mathrm{CO}_{2}$ gas generated during the mineralization of HBCD subsequently dissolved in the water, which also lead to a decrease in $\mathrm{pH}$. 
At the same time, there are some small molecules of carboxylic acids generated in the degradation of $\mathrm{HBCD}$, which also cause the decrease in $\mathrm{pH}$. As mentioned above, the degradation rate of $\mathrm{HBCD}$ reached $96.5 \%$ when the reaction proceeded to $180 \mathrm{~min}$. It is indicated that the intermediate in the solution is rapidly decomposed into small molecular of carboxylic acids, and further mineralized to $\mathrm{CO}_{2}$ and $\mathrm{H}_{2} \mathrm{O}$, so that the $\mathrm{pH}$ of the solution continued to decrease as the reaction time prolonged. The increasing concentration of bromide ions in the solution and the decreasing $\mathrm{pH}$ value indicate that $\mathrm{HBCD}$ is highly mineralized in $\mathrm{UV} / \mathrm{TiO}_{2} / \mathrm{KPS}$ homo/heterogeneous photocatalysis.

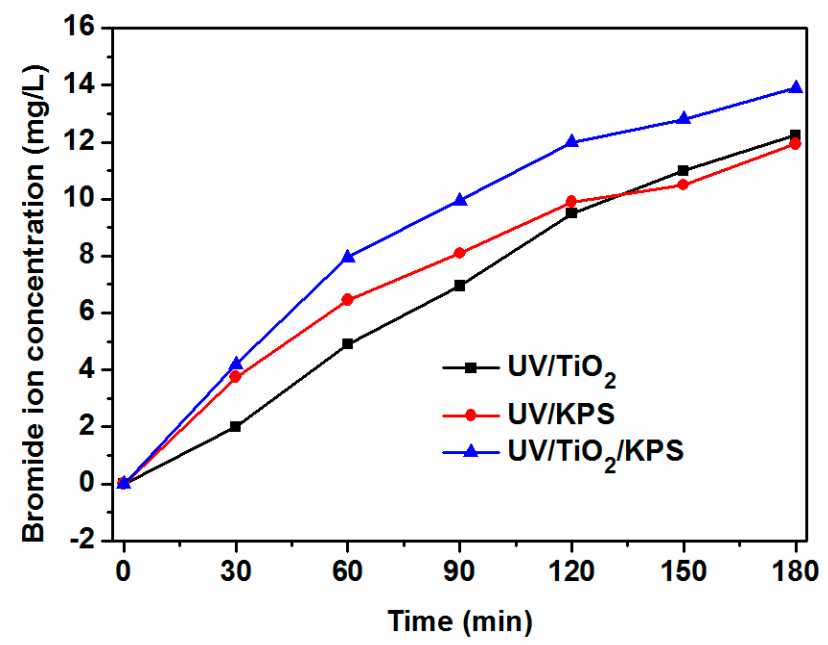

Figure 4. The change of bromide ion in water samples from different time points (the initial concentration of $\mathrm{HBCD}$ is $25.0 \mathrm{mg} / \mathrm{L}$, KPS dosage is $4 \mathrm{mg} / \mathrm{L}$, and $\mathrm{TiO}_{2}$ dosage is $100 \mathrm{mg} / \mathrm{L}$ ).

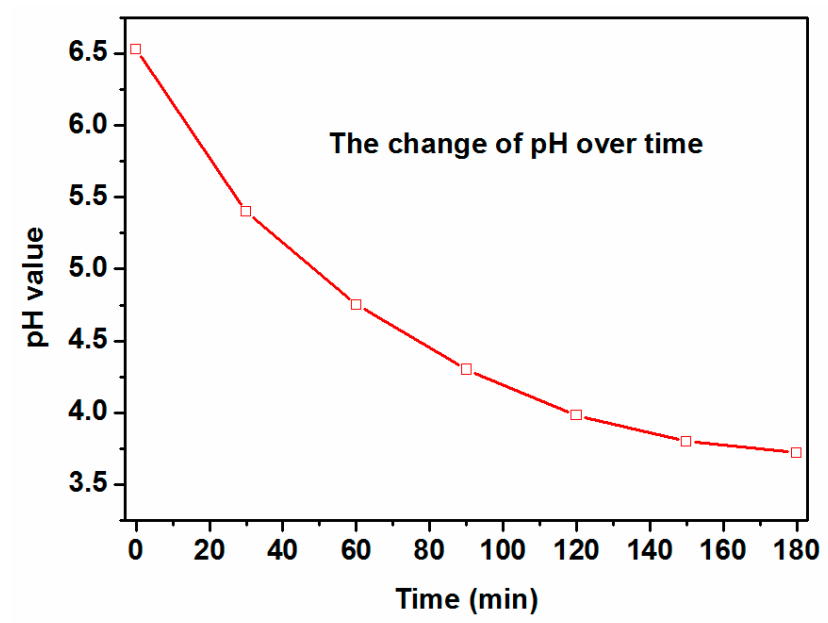

Figure 5. The change of $\mathrm{pH}$ over time (the initial concentration of HBCD is $25.0 \mathrm{mg} / \mathrm{L}$, KPS dosage is $4 \mathrm{mg} / \mathrm{L}$, and $\mathrm{TiO}_{2}$ dosage is $100 \mathrm{mg} / \mathrm{L}$ ).

\subsection{The Mechanism of Photodegradation of $H B C D$}

Figure 6 shows the mass spectrum of the intermediates obtained by GC-MS analysis. The solution was sampled during the degradation of $\mathrm{HBCD}$ in the UV/ $/ \mathrm{TiO}_{2} / \mathrm{KPS}$ system at $90 \mathrm{~min}$, with the reaction conditions the same as mentioned above. The mass spectrum of degradation products were tetrabromocyclododecene (A), dibromocyclododecadiene (B), 1,5,9-Cyclododecatriene (C), 1,2-Epoxy-5,9-cyclododecadiene (D), dibromo-epoxy-cyclododecene (E), 4,5-dibromooctanedioic acid $(F)$, and succinic acid $(G)$, respectively [31-33]. 

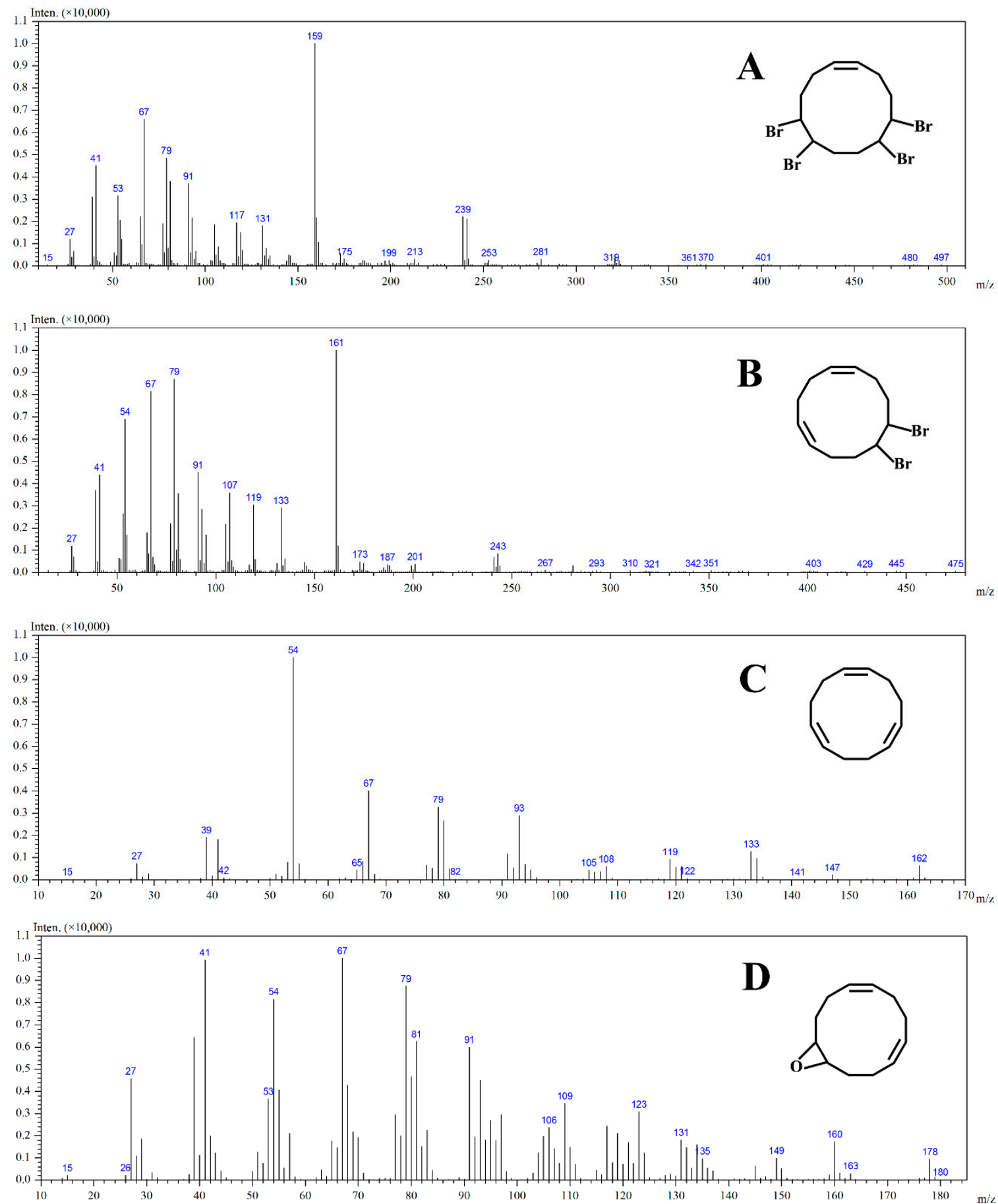

Figure 6. Cont. 

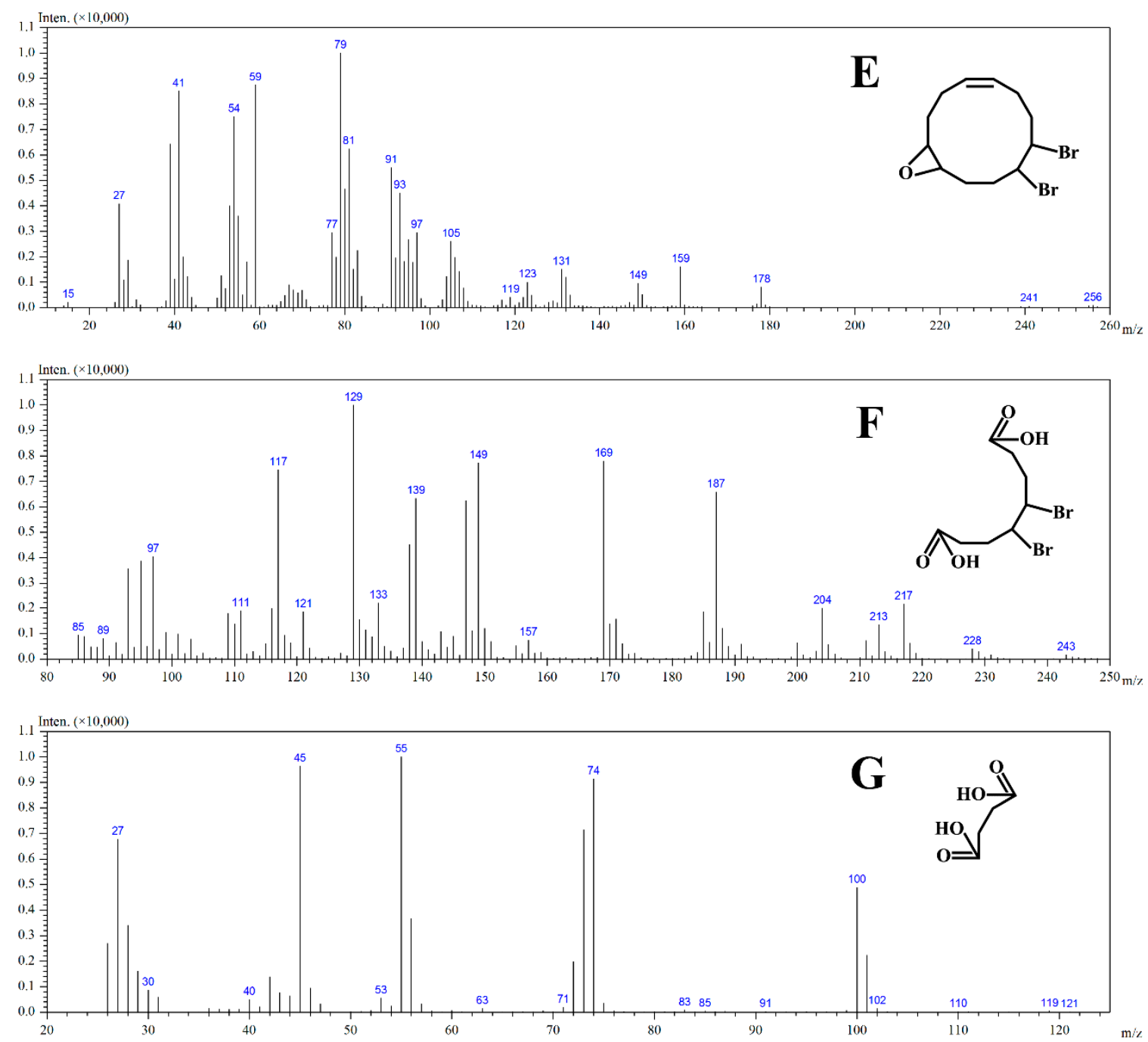

Figure 6. The mass spectrum of the intermediates in the $\mathrm{UV} / \mathrm{TiO}_{2} / \mathrm{KPS}$ system at $90 \mathrm{~min}$ ((A) Tetrabromocyclododecene; (B) Dibromocyclododecadiene; (C) 1,5,9-Cyclododecatriene; (D) 1,2-Epoxy-5,9-cyclododecadiene; (E) Dibromo-epoxy-cyclododecene; (F) 4,5-dibromooctanedioic acid; (G) succinic acid).

By analyzing the degradation products of GC/MS, the possible degradation pathway of $\mathrm{HBCD}$ in $\mathrm{UV} / \mathrm{TiO}_{2} / \mathrm{KPS}$ system is determined, as shown in Figure 7. Under the action of active free radicals, two adjacent $\mathrm{C}-\mathrm{Br}$ bonds in the molecular structure of $\mathrm{HBCD}$ undergo cleavage and debromination to form carbon-carbon double bonds, thus the compounds A, B, and C were obtained successively [34]. Compound $\mathrm{C}$ can be directly oxidized to $\mathrm{D}$ or oxidized to $\mathrm{G}$ by double bond cleavage. In addition, the compound $\mathrm{B}$ can also be oxidized to form the compound $\mathrm{E}$, or oxidized to $\mathrm{F}$ and $\mathrm{G}$ by double bond cleavage [35]. The compound F can also be further debrominated and oxidized to form G. Succinic acid $(\mathrm{G})$ is a small molecule, and it can be easily degraded by free radicals (like $\mathrm{SO}_{4}{ }^{\bullet-}$ and $\mathrm{OH}^{\bullet}$ ) into carboxylic acids, $\mathrm{CO}_{2}$, and $\mathrm{H}_{2} \mathrm{O}$ in the following time. The adsorption of intermediate species on the surface of $\mathrm{TiO}_{2}$ may cover the active sites, which may result in a decrease in catalytic efficiency. But in this work, the initial concentration of HBCD is very low $(25 \mathrm{mg} / \mathrm{L})$, and under the irradiation of UV irradiation, the surface of the titanium dioxide is hydrophilic, so the organic intermediates are more easily dispersed into the water-methanol mixed solution under strong stirring. 


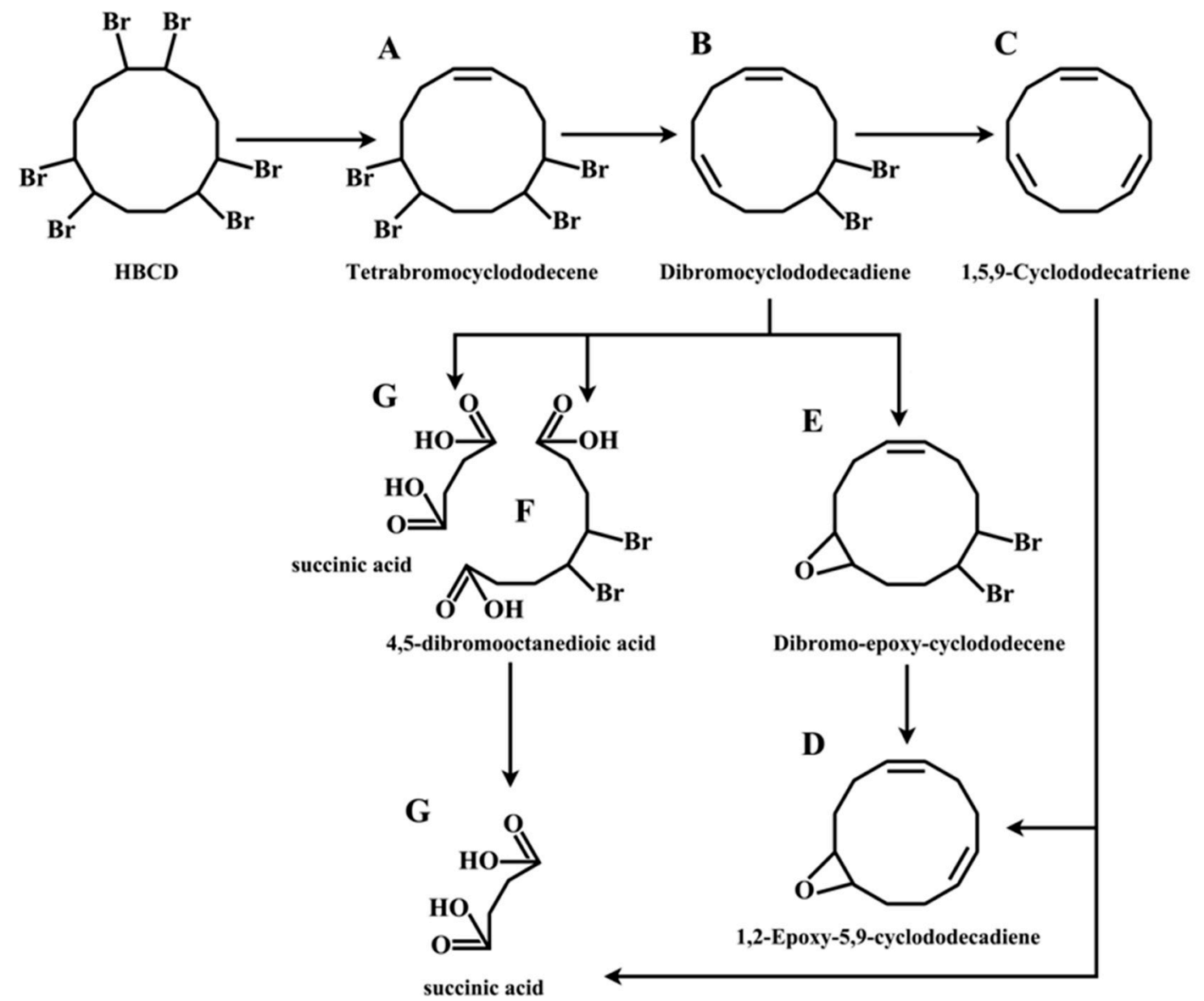

Figure 7. Possible pathways of degradation of $\mathrm{HBCD}$ in $\mathrm{UV} / \mathrm{TiO}_{2} / \mathrm{KPS}$ systems.

\section{Materials and Methods}

\subsection{Reagents}

Ethanol (HPLC grade) and acetonitrile (HPLC grade) were supplied by LABSCIENCE (Reno, NV, USA) and TEDIA (Nashville, TN, USA), respectively. HBCD (99.0\%), sodium carbonate (99.8\%), sodium bicarbonate $(99.5 \%)$, sodium nitrite $(99.0 \%)$, potassium persulfate (KPS, 99\%), dichloromethane (HPLC grade), anhydrous sodium sulfate (99.0\%) and methanol (HPLC grade) were supplied by Sinopharm Chemical Reagent Co., Ltd (Shanghai, China). All reagents were used as received without further purification. $\mathrm{TiO}_{2}$ nanoparticles were laboratory-made, as described in the previous literature [26].

The preparation of HBCD stock solution was as follows: accurately weigh $0.05 \mathrm{~g}$ of HBCD powder into $100 \mathrm{~mL}$ volumetric flasks, and add chromatographically pure methanol to the $100 \mathrm{~mL}$ mark. After dissolving, the HBCD stock solution with the concentrations of $500.00 \mathrm{mg} / \mathrm{L}$ was obtained, and then it was stored in a refrigerator at $4{ }^{\circ} \mathrm{C}$ for later use. The HBCD stock solution was diluted by ultrapure water to different concentrations for drawing the peak area-concentration standard curve, and it also be used as pollutants in the photodegradation experiments.

\subsection{Photodegradation of $H B C D$}

The photoreactor was supplied by Xujiang Electromechanical Plant (XPA-7, Nanjing, China). For determination of $\mathrm{TiO}_{2}$ dosages, a $50 \mathrm{~mL}$ HBCD water-methanol mixture solution with the concentration of $25.00 \mathrm{mg} / \mathrm{L}$ was added into a quartz tube, and then $\mathrm{TiO}_{2}$ powder with different dosages $(0 \sim 400 \mathrm{mg} / \mathrm{L})$ were also added into the tube. For determination of the effect of KPS dosage, a $50 \mathrm{~mL} \mathrm{HBCD}$ water-methanol mixture solution with the concentration of $25.00 \mathrm{mg} / \mathrm{L}$ was added into 
a quartz tube, and then $\mathrm{TiO}_{2}$ powder with the dosage of $100 \mathrm{mg} / \mathrm{L}$ and $\mathrm{KPS}$ with different dosages $(1 \sim 8 \mathrm{mM})$ were also added into the tube. For the kinetic analysis, the photodegradation of HBCD in the three systems of "UV/ $\mathrm{TiO}_{2}\left(\mathrm{TiO}_{2}: 100 \mathrm{mg} / \mathrm{L}\right)$ ", "UV/ $\mathrm{K}_{2} \mathrm{~S}_{2} \mathrm{O}_{8}$ (KPS: $\left.4 \mathrm{mM}\right)$ ", and " $\mathrm{TiO}_{2}\left(\mathrm{TiO}_{2}\right.$ : $100 \mathrm{mg} / \mathrm{L})+\mathrm{K}_{2} \mathrm{~S}_{2} \mathrm{O}_{8}$ (KPS: $4 \mathrm{mM}$ )" were performed, respectively. In all of the above experimental systems, after all the reagents were completely added, the mixed solution was placed in dark and stirred for $60 \mathrm{~min}$ to allow all the reagents to be uniformly mixed and to achieve adsorption equilibrium between $\mathrm{TiO}_{2}$ particles (if any) and HBCD in the solution system. Then, turn on the cooling water and the $100 \mathrm{~W}$ mercury light source to start the photocatalytic reaction. Quickly take $2 \mathrm{~mL}$ of the sample at intervals of $30 \mathrm{~min}$, place it in a tube containing $2 \mathrm{~mL}$ of methanol, mix well by shaking, and filter through a $0.22 \mu \mathrm{m}$ filter. The filtrate was loaded into the sample vial for analysis in a liquid chromatograph. The average of 3 parallel determinations was taken as the concentration of each sample.

For the measurement of bromide ion concentration, a sample solution was quenched right after the sample was taken out by using a same volume of $0.2 \mathrm{M}$ sodium nitrite solution. Then supernatant and the $\mathrm{TiO}_{2}$ nanoparticles were separated in the same method. The supernatant was used to measure the concentration of bromide ion.

\subsection{Analysis Method}

Concentrations of HBCD were measured by a high-performance liquid chromatography (HPLC, LC-20AD, Shimadzu, Kyoto, Japan) instrument equipped with UV-vis detector set at $210 \mathrm{~nm}$. The mobile phase was acetonitrile/water $(85 / 15(v / v))$ and the flow rate was maintained at $1.0 \mathrm{~mL} / \mathrm{min}$. The HPLC chromatogram of HBCD was shown in Figure S2 (Supporting Information). According to the change of concentration of $\mathrm{HBCD}$ before and after degradation of the reaction system, the degradation rate of HBCD was calculated. The calculation was as follows:

$$
\eta_{\mathrm{HBCD}}=\frac{\mathrm{C}_{0}-\mathrm{C}_{\mathrm{t}}}{\mathrm{C}_{0}} \times 100 \%
$$

where $C_{0}$ represents the initial concentration of $H B C D$ in the reaction system and $C_{t}$ represents the concentration of HBCD in the system at time $t$.

Concentration of bromide ion was measured by a Diane Ion chromatograph (ICS1100, Dionex, Sunnyvale, CA, USA) with an IonPac AS23 anion analytical column $(250 \mathrm{~mm} \times 4.0 \mathrm{~mm} \times 5 \mu \mathrm{m}$, Dionex, Sunnyvale, CA, USA) and a Dionex IonPac AG22 anion protective column $(50 \mathrm{~mm} \times 4 \mathrm{~mm}$, Dionex, Sunnyvale, CA, USA). The peak area-concentration standard curve of $\mathrm{Br}$ ion was plotted using potassium bromide powder as the bromine source. Leaching solution was $4.5 \mathrm{mM} \mathrm{Na}_{2} \mathrm{CO}_{3}$ and $1.4 \mathrm{mM} \mathrm{NaHCO} 3$ with a flow rate of $1.2 \mathrm{~mL} / \mathrm{min}$.

The intermediates were qualitatively analyzed by a gas chromatography/mass spectrometry (GC/MS, Shimadzu QP2010 plus). The inlet temperature of GC is 200 degrees with the column type of DB-5MS capillary column $(30 \mathrm{~m} \times 0.25 \mathrm{~mm} \times 0.25 \mu \mathrm{m}$, Agilent, Santa Clara, CA, USA). The injection volume is $1 \mu \mathrm{L}$, and the carrier gas is high purity nitrogen $(99.999 \%)$. The ion source temperature, the electron bombardment energy, and the scanning mode of the mass spectrometer is $240{ }^{\circ} \mathrm{C}, 70 \mathrm{eV}$, and full scan mode $(15 \sim 500 \mathrm{~m} / \mathrm{z})$, respectively. The sample solution was pretreated by extraction by dichloromethane and passed through anhydrous sodium sulfate, then it was concentrated by evaporation to about $1 \mathrm{~mL}$ under nitrogen, and passed through a $0.45 \mu \mathrm{m}$ filter before the GC/MS analysis.

\section{Conclusions}

Degradation of $\mathrm{HBCD}$ is investigated in the $\mathrm{UV} / \mathrm{TiO}_{2}, \mathrm{UV} / \mathrm{KPS}$, and $\mathrm{UV} / \mathrm{TiO}_{2} / \mathrm{KPS}$ system by measurement of the concentrations of $\mathrm{HBCD}$ and bromide ion. $\mathrm{HBCD}$ can be almost completely degraded and $74.3 \%$ of the total bromine content is achieved in the $\mathrm{UV} / \mathrm{TiO}_{2} / \mathrm{KPS}$ homo/heterogeneous photocatalysis, much more than in the UV/KPS system and the UV/ $\mathrm{TiO}_{2}$ 
system. The $\mathrm{SO}_{4}{ }^{\bullet-}$ produced in persulphate and $\mathrm{OH}^{\bullet}$ radicals produced in $\mathrm{TiO}_{2}$ photocatalysis have synergistic effects in the degradation of $\mathrm{HBCD}$ in the $\mathrm{UV} / \mathrm{TiO}_{2} / \mathrm{KPS}$ homo/heterogeneous photocatalysis. The high yield of the concentration of bromide ions in the solutions indicates that fewer intermediates are formed in the $\mathrm{UV} / \mathrm{TiO}_{2} / \mathrm{KPS}$ homo/heterogeneous photocatalysis of $\mathrm{HBCD}$. The efficient UV/ $\mathrm{TiO}_{2} / \mathrm{KPS}$ homo/heterogeneous system would provide great impetus to pollution control and environmental management.

Supplementary Materials: The following are available online at http:/ /www.mdpi.com/2073-4344/9/2/189/s1, Figure S1: Photocatalysis for $\mathrm{HBCD}$ degradation in the $\mathrm{UV} / \mathrm{TiO}_{2} / \mathrm{KPS}$ system with three time cycling uses, Figure S2: The HPLC chromatogram of HBCD.

Author Contributions: Conceptualization, Q.L.; methodology, L.W.; formal analysis, L.Z.; investigation, X.F.; resources and data curation, J.L.; writing—original draft preparation, Q.L.; writing-review and editing, L.Z.; and H.X.

Funding: This research was funded by Natural Science Foundation of China (No. 21806101), Natural Science Foundation of Shanghai (Nos. 16ZR1412600, 15ZR1401200), Gaoyuan Discipline of Shanghai-Environmental Science and Engineering (Resource Recycling Science and Engineering), Innovation Research Grant (13YZ130) and Leading Academic Discipline Project (J51803) from the Shanghai Education Committee.

Conflicts of Interest: The authors declare no conflicts of interest.

\section{References}

1. Almughamsi, H.; Whalen, M.M. Hexabromocyclododecane and tetrabromobisphenol A alter secretion of interferon gamma (IFN-gamma) from human immune cells. Arch. Toxicol. 2016, 90, 1695-1707. [CrossRef] [PubMed]

2. Alaee, M.; Arias, P.; Sjodin, A.; Bergman, A. An overview of commercially used brominated flame retardants, their applications, their use patterns in different countries/regions and possible modes of release. Environ. Int. 2003, 29, 683-689. [CrossRef]

3. Jeannerat, D.; Pupier, M.; Schweizer, S.; Mitrev, Y.N.; Favreau, P.; Kohler, M. Discrimination of hexabromocyclododecane from new polymeric brominated flame retardant in polystyrene foam by nuclear magnetic resonance. Chemosphere 2016, 144, 1391-1397. [CrossRef] [PubMed]

4. Li, L.; Weber, R.; Liu, J.G.; Hu, J.X. Long-term emissions of hexabromocyclododecane as a chemical of concern in products in China. Environ. Int. 2016, 91, 291-300. [CrossRef]

5. Hunziker, R.W.; Gonsior, S.; Macgregor, J.A.; Desjardins, D. Fate and effect of hexabromocyclododecane in the environment. Organohalogen Compd. 2004, 66, 2300-2305.

6. Stiborova, H.; Vrkoslavova, J.; Pulkrabova, J.; Poustka, J.; Hajslova, J.; Demnerova, K. Dynamics of brominated flame retardants removal in contaminated wastewater sewage sludge under anaerobic conditions. Sci. Total Environ. 2015, 533, 439-445. [CrossRef] [PubMed]

7. Wagoner, E.R.; Baumberger, C.P.; Peverly, A.A.; Peters, D.G. Electrochemical reduction of 1, 2, 5, 6, 9, 10-hexabromocyclododecane at carbon and silver cathodes in dimethylformamide. J. Electroanal. Chem. 2014, 713, 136-142. [CrossRef]

8. Zhang, K.; Huang, J.; Wang, H.; Liu, K.; Yu, G.; Deng, S.B.; Wang, B. Mechanochemical degradation of hexabromocyclododecane and approaches for the remediation of its contaminated soil. Chemosphere 2014, 116, 40-45. [CrossRef] [PubMed]

9. Takigami, H.; Watanabe, M.; Kajiwara, N. Destruction behavior of hexabromocyclododecanes during incineration of solid waste containing expanded and extruded polystyrene insulation foams. Chemosphere 2014, 116, 24-33. [CrossRef] [PubMed]

10. Jondreville, C.; Cariou, R.; Meda, B.; Dominguez-Romero, E.; Omer, E.; Dervilly-Pinel, G.; Le Bizec, B.; Travel, A.; Baeza, E. Accumulation of a-hexabromocyclododecane (alpha-HBCDD) in tissues of fast- and slow-growing broilers (Gallus domesticus). Chemosphere 2017, 178, 424-431. [CrossRef]

11. Guo, Y.G.; Lou, X.Y.; Xiao, D.X.; Xu, L.; Wang, Z.H.; Liu, J.S. Sequential reduction-oxidation for photocatalytic degradation of tetrabromobisphenol A: Kinetics and intermediates. J. Hazard. Mater. 2014, 241-242, 301-306. [CrossRef] [PubMed] 
12. Saien, J.; Ojaghloo, Z.; Soleymani, A.R.; Rasoulifard, M.H. Homogeneous and heterogeneous AOPs for rapid degradation of Triton X-100 in aqueous media via UV light, nano titania hydrogen peroxide and potassium persulfate. Chem. Eng. J. 2011, 167, 172-182. [CrossRef]

13. Salari, D.; Niaei, A.; Aber, S.; Rasoulifard, M.H. The photooxidative destruction of CI basic yellow 2 using $\mathrm{UV} / \mathrm{S}_{2} \mathrm{O}_{8}{ }^{2-}$ process in a rectangular continuous photoreactor. J. Hazard. Mater. 2009, 166, 61-66. [CrossRef] [PubMed]

14. Zhang, L.; Zhang, Q.H.; Xie, H.Y.; Guo, J.; Lyu, H.L.; Li, Y.G.; Sun, Z.G.; Wang, H.Z.; Guo, Z.H. Electrospun titania nanofibers segregated by graphene oxide for improved visible light photocatalysis. Appl. Catal. B Environ. 2017, 201, 470-478. [CrossRef]

15. Zhang, L.; Li, Y.G.; Xie, H.Y.; Wang, H.Z.; Zhang, Q.H. Efficient mineralization of toluene by W-doped $\mathrm{TiO}_{2}$ nanofibers under visible light irradiation. J. Nanosci. Nanotechnol. 2015, 15, 2944-2951. [CrossRef]

16. Zhang, L.; Li, Y.G.; Zhang, Q.H.; Shi, G.Y.; Wang, H.Z. Fast synthesis of highly dispersed anatase $\mathrm{TiO}_{2}$ nanocrystals in a microfluidic reactor. Chem. Lett. 2011, 40, 1371-1373. [CrossRef]

17. Aronne, A.; Fantauzzi, M.; Imparato, C.; Atzei, D.; De Stefano, L.; D'Errico, G.; Sannino, F.; Rea, I.; Pirozzi, D.; Elsener, B.; et al. Electronic properties of $\mathrm{TiO}_{2}$-based materials characterized by high $\mathrm{Ti}^{3+}$ self-doping and low recombination rate of electron-hole pairs. RSC Adv. 2017, 7, 2373-2381. [CrossRef]

18. Sannino, F.; Pernice, P.; Imparato, C.; Aronne, A.; D'Errico, G.; Minieri, L.; Perfetti, M.; Pirozzi, D. Hybrid $\mathrm{TiO}_{2}$-acetylacetonate amorphous gel-derived material with stably adsorbed superoxide radical active in oxidative degradation of organic pollutants. RSC Adv. 2015, 5, 93831-93839. [CrossRef]

19. Sannino, F.; Pernice, P.; Minieri, L.; Gamandona, G.A.; Aronne, A.; Pirozzi, D. Oxidative Degradation of Different Chlorinated Phenoxyalkanoic Acid Herbicides by a Hybrid $\mathrm{ZrO}_{2}$ Gel-Derived Catalyst without Light Irradiation. ACS Appl. Mater. Interfaces 2015, 7, 256-263. [CrossRef]

20. Guo, Y.G.; Zhou, J.; Lou, X.Y.; Liu, R.L.; Xiao, D.X.; Fang, C.L.; Wang, Z.H.; Liu, J.S. Enhanced degradation of Tetrabromobisphenol A in water by a UV/base/persulfate system: Kinetics and intermediates. Chem. Eng. J. 2014, 254, 538-544. [CrossRef]

21. Neta, P.; Huie, R.E.; Ross, A.B. Rate constants of inorganic radicals in aqueous-solution. J. Phys. Chem. Ref. Data 1988, 17, 1027-1284. [CrossRef]

22. Xu, J.; Meng, W.; Zhang, Y.; Lei, L.; Guo, C.S. Photocatalytic degradation of tetrabromobisphenol A by mesoporous BiOBr: Efficacy, products and pathway. Appl. Catal. B Environ. 2011, 107, 355-362. [CrossRef]

23. Zhao, J.Y.; Zhang, Y.B.; Quan, X.; Chen, S. Enhanced oxidation of 4-chlorophenol using sulfate radicals generated from zero-valent iron and peroxydisulfate at ambient temperature. Sep. Purif. Technol. 2010, 71, 302-307. [CrossRef]

24. Li, Q.; Wang, L.F.; Zhang, L.; Xie, H.Y. Rapid degradation of tetrabromobisphenol A under the UV/TiO $2 / \mathrm{KPS}$ systems in alkaline aqueous solutions. Res. Chem. Intermed. 2018. [CrossRef]

25. Ahmadi, M.; Ghanbari, F.; Moradi, M. Photocatalysis assisted by peroxymonosulfate and persulfate for benzotriazole degradation: Effect of $\mathrm{pH}$ on sulfate and hydroxyl radicals. Water Sci. Technol. 2015, 72, 2095-2102. [CrossRef] [PubMed]

26. Xie, H.Y.; Zhu, L.P.; Wang, L.L.; Chen, S.W.; Yang, D.D.; Yang, L.J.; Gao, G.L.; Yuan, H. Photodegradation of benzene by $\mathrm{TiO}_{2}$ nanoparticles prepared by flame CVD process. Particuology 2011, 9, 75-79. [CrossRef]

27. Yang, H.; Zhou, S.L.; Yin, M.L.; Pi, L.L.; Zeng, J.; Yi, B. Parameters effect on photocatalytic kinetics of carbofuran in $\mathrm{TiO}_{2}$ aqueous solution. China Environ. Sci. 2013, 33, 82-87.

28. Varanasi, L.; Coscarelli, E.; Khaksari, M.; Mazzoleni, L.R.; Minakata, D. Transformations of dissolved organic matter induced by UV photolysis, hydroxyl radicals, chlorine radicals, and sulfate radicals in aqueous-phase UV-Based advanced oxidation processes. Water Res. 2018, 135, 22-30. [CrossRef] [PubMed]

29. Li, W.; Jain, T.; Ishida, K.; Liu, H.Z. A mechanistic understanding of the degradation of trace organic contaminants by UV/hydrogen peroxide, UV/persulfate and UV/free chlorine for water reuse. Environ. Sci. Water Res. Technol. 2017, 3, 128-138. [CrossRef]

30. Elmolla, E.S.; Chaudhuri, M. Degradation of amoxicillin, ampicillin and cloxacillin antibiotics in aqueous solution by the UV/ZnO photocatalytic process. J. Hazard. Mater. 2010, 173, 445-449. [CrossRef] [PubMed]

31. Barontini, F.; Cozzani, V.; Cuzzola, A.; Petarca, L. Investigation of hexabromocyclododecane thermal degradation pathways by gas chromatography/mass spectrometry. Rapid Commun. Mass Spectrom. 2001, 15, 690-698. [CrossRef] [PubMed] 
32. Zhou, D.N.; Chen, L.; Wu, F.; Wang, J.; Yang, F. Debromination of hexabromocyclododecane in aqueous solutions by UV-C irradiation. Fresenius Environ. Bull. 2012, 21, 107-111.

33. Yu, Y.; Zhou, D.; Wu, F. Mechanism and products of the photolysis of hexabromocyclododecane in acetonitrile-water solutions under a UV-C lamp. Chem. Eng. J. 2015, 281, 892-899. [CrossRef]

34. Zhao, Y.Y.; Zhang, X.H.; Sojinu, O.S. Thermodynamics and photochemical properties of alpha, beta, and gamma-hexabromocyclododecanes: A theoretical study. Chemosphere 2010, 80, 150-156.

35. Tso, C.P.; Shih, Y.H. The transformation of hexabromocyclododecane using zerovalent iron nanoparticle aggregates. J. Hazard. Mater. 2014, 277, 76-83. [CrossRef] [PubMed]

C 2019 by the authors. Licensee MDPI, Basel, Switzerland. This article is an open access article distributed under the terms and conditions of the Creative Commons Attribution (CC BY) license (http://creativecommons.org/licenses/by/4.0/). 